\title{
How to Do Things with Affects
}

\author{
Affective Triggers in Aesthetic Forms \\ and Cultural Practices
}

\author{
Edited by \\ Ernst van Alphen and Tomáš Jirsa
}

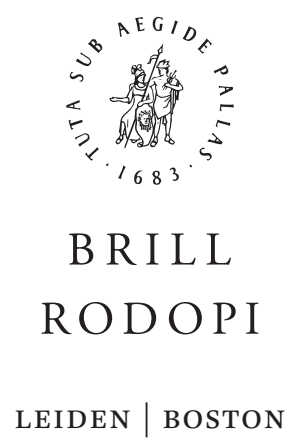

For use by the Author only | ( 2019 Koninklijke Brill NV 


\title{
Contents
}

\author{
Notes on Contributors VII \\ Introduction: Mapping Affective Operations $\quad 1$ \\ Ernst van Alphen and Tomáš Jirsa
}

\section{PART 1}

Triggering the Affects

1 Reading Irony through Affect: the Non-Sovereign Ironic Subject in C.P. Cavafy's Diary 17

Maria Boletsi

2 (An)Aesthetics of Affect: the Case of Hyper-Realism 40 Pietro Conte

3 Relational Affect: Perspectives from Philosophy and Cultural Studies 59 Jan Slaby

4 (Nearly) Nothing to Express : Horror : some Tread: a Toroid 82 Eugenie Brinkema

5 Integrating Affect and Language: Essayism as an Affective Practice in Robert Musil's The Man Without Qualities 100 Anne Fleig and Matthias Lüthjohann

\section{PART 2}

Sensations, Resonances, and Transformations

6 Affective Disfigurations: Faceless Encounters between Literary Modernism and the Great War 121 TomášJirsa

$7 \quad$ Monstrous Resonances: Affect and Animated Pornography 143 Susanna Paasonen 
8 Reading for Affects: Francis Bacon and the Work of Sensation 163 Ernst van Alphen

\section{PART 3}

Affects as Triggers

9 Affectively Effective: Affect as an Artistic-Political Strategy 179 Mieke Bal

10 Affect Is the Medium 200 Christiane Voss

11 Et in Academia Ego: Affect and Academic Writing 216 Bernd Herzogenrath

12 The Arab Spring's Stranger: the Affective Media Phenomenon of The Girl in the Blue Bra 235 Christina Riley

13 Affective Exchange in Portraiture: to Follow J. Jackie Baier into the Photographic Dissolve 253

Eliza Steinbock

Name Index $\quad 275$ 


\title{
Affective Exchange in Portraiture: to Follow J. Jackie Baier into the Photographic Dissolve
}

\author{
Eliza Steinbock
}

\begin{abstract}
Filmmaker and photographer J. Jackie Baier stated in an interview that she "follows the protagonist, always." Her portraiture projects begin with establishing a collaborative relationship through and in the camera. The result is often the black and white grainy aesthetic of night photography, which captures someone barely emerging in the mist of the night, on the prowl. In my following of Jackie into the photographic dissolve, I contend that affect's analysis - there, at the point of indication-involves at least one subject that participates in the affective exchange, and also I argue that affect is a virtual force with the potential to be activated. The exchange of affect in portraiture as I analyze it here is 1) between Jackie the portraitist and her muses, 2) between those muses's bodies forming in her portrayals and the viewer, but also 3 ) between the researcher and the protagonists of my research portraits. I propose that Jackie Baier's dedicated aesthetic of following her trans feminine muses - in the documentary film JULIA, and photographs of REAL COOL TIME, and the Royal Project-activate the affective operations of interest and love to capture individuation on the brink of dissolve.
\end{abstract}

Filmmaker and photographer J. Jackie Baier stated in an interview that she "follows the protagonist, always" in order to do justice to who her muse becomes over time (Steinbock 2015). Jackie's documentary films House of Shame: Chantal All Night Long (2010), JULIA (2013), and Bianca, Or Love Is All You Need (in production) all follow fellow trans women in Berlin for five to ten years crisscrossing clubs, streets, and residences, where shifting senses of self emerge. ${ }^{1}$ These and other portraiture projects begin with establishing a collaborative relationship through and in the camera. The result is often the black and white grainy aesthetic of night photography, which captures someone barely emerging in the mist of the night, on the prowl. Affect is the "very indication

1 Baier's website: fotografie.jackiebaier.de.

(C) KONINKLIJKE BRILL NV, LEIDEN, 2019 | DOI:10.1163/9789004397712_015

For use by the Author only | ( 2019 Koninklijke Brill NV 
of bodies forming in the transmission of force or intensity," writes Patricia Clough (2010: 224). These "bodies" are not only human though; in their formation through intensities they become a nexus for affective operations structuring singular relations between subjectivity, sociality and technology that I see fomenting in art making. In my following of Jackie into the photographic dissolve, I contend that affect's analysis - there, at the point of indicationinvolves at least one subject that participates in the affective exchange, and also I argue that affect is a virtual force with the potential to be activated. The on-goingness of the affective process and substantive materiality of the subject's portrait require that I treat both ends-subjectivity and virtual forceas sources of affective activity contributing to a sense of an exchange taking place. To be clear, the exchange of affect in portraiture as I analyze it here is 1) between Jackie the portraitist and her muses, 2) between those muses's bodies forming in her portrayals and the viewer, but also 3 ) between the researcher and the protagonists of my research portraits.

In short, I argue that in studying the process of art-making, rather than only a final, formal product, my analysis of affective operations triangulates human subjects, the social prosthesis of the camera in this case, and the psychic apparatus of feeling. Hence, in this chapter I combine Deleuzian theorists who circumscribe affect in terms of intensity or force in excess of subjectivity with Tomkins-oriented theorists who emphasize socio-psychic transformations in and between subjects. Though often pitted against each other as incompatible models, for instance differing by ascertaining the nameable affects or "affect" as such, I see the possibility of their connection through Clough's posthuman attention to affect marking the formation of bodies, which grasps the ways affect as force lights up, amplifies or deflates bodies and how social scripts such as love or grief overlay these experiences. In terms of my formal analysis of Jackie's images, Eugenie Brinkema and Sianne Ngai among others have brilliantly shown how singular forms in aesthetics, in cinema, art or literature trigger specific affects (Brinkema 2014; Ngai 2005: 212). Jackie's photographic aesthetic prompts me to ask, what then is the affective infrastructure of being out-of-focus? In this chapter, I propose that Jackie Baier's documentary films and photographs of trans feminine muses, her alluring "nocturnal creatures"to borrow a title from her early solo exhibition-, activate the affective operations of interest and love to capture individuation on the brink of dissolve.

In our intermittent conversations from 2014-2018 Jackie has shared insights about her lens-based practice, information on her personal, professional and aesthetic background as well as allowed me to observe her work documenting events, queer parties and making portraits. Jackie's more than 40-year career in film, television, and visual art makes her one of the most diversely experienced 
artists within the field of transgender portraiture. ${ }^{2}$ Though she has worked in many mediums, since transitioning she spent a decade amassing photographic studies of a number of transsexual women whom she has met in either commercial or non-commercial sexual spaces, who also star in her documentary film series. For example, Jackie is completing the Royal Project that rephotographs and interviews her trans sex worker colleagues from when she worked at the Royal trans hostess bar in Berlin during 2003-4, to relay where life has taken them.

The material under consideration deals less with typical concerns of documentary, like authenticity, instead drawing out issues of how fragmented and fetishized cinematic "body" and "voice" (Heath 1981: 178) — trans bodies in particular-are co-constructed by filmmaker and protagonist-cum-muse, and those who follow them in turn. The perception of trans femininities that Jackie develops through her extended portraiture practice is in Nikki Sullivan's words, "both the vehicle and the effect of a particular situated somatechnics" (2012: 302) that attunes her bodily-being-in-the-world "I" with the dispositif "eye." The meeting point of the camera lens is an inextricable twist of soma and techné, the pressed glass a vibrant matter binding together perceptual acts that insist on co-implication and co-responsible relationships. Through her camera, Jackie and her muses collaboratively accomplish and assert a somatechnical transgender gaze. Differently from Jack Halberstam's (2005: 86-87) analysis of shot/reverse-shots that temporarily suture viewers to the point of view of the transgender protagonist under duress, Jackie's muse-oriented portraits have prompted me to attend to how durational portraiture might sustain a shared transgender gaze within its situated perception and orientation to the world.

British anthropologist Tim Ingold has guided my ethnographic approach to studying trans aesthetics emerging on the fly and within affective operations. He calls the method of describing encounters more an art than a science, and suggests foregrounding the practice of learning to attend (2014: 385,389$)$. This requires the ethnographer "to attend to what others are doing and saying [...] to follow along where others go and to do their bidding" (389). The form of participant observation I practice involves observing from within my cultural worker/analyst role, not objectifying but attending to the incipient cusp of persons and things, then seeking to follow in their precept. Hence, I want to distinguish my writing here from the writing up of fieldwork, a reportage, or pure description, as if I could be neutral in my correspondence, or disengaged from co-imagining possible futures. Subsequently, I try to foreground awareness of

2 For more information about my larger research project on trans portraiture, see http://www. elizasteinbock.com/about/vital-art-project/. 
the limitations of any portrayal's truth-value and note my own participation in affective exchanges.

Creating a research portrait differs from the "ethnographic portrait," which is a method pioneered by Sara Lawrence-Lightfoot (1997), an anthropologist of education who invests in naturalistic observation. What I do take from her practice is a focus on comprehending an individual's successful strategies for overcoming challenges: in short, celebrating and sharing what is working as best practices. Art historians are increasingly conducting research aware of the social embeddedness of the artist, but adapting ethnographic methods has thus far been justified by a need to research artists whose own practice is process-based, lacking a substantial formal result to analyze. While I research in-situ, it is not because there is no formal result that could be called the artwork. Rather, I want to foreground the process: the success of collaboration as a trans resilience technique, the messy activity of creating a portrait of someone who has been previously excluded from the tradition, how decisions are made selecting materials and editing work, and interconnections between technical training and artistic vision.

The following four scenes from my encounters with Jackie focus on the affective and aesthetic operations of love and interest, dissolution, pain, and opacity. They offer an analysis developed closely with her, and so I have tried in my writing style to retain her "following" aesthetic, or at least to bear in mind how in following the protagonist she attends to them in ways that activate affective operations. The scenes comprise a fragment of my research portrait that follows Jackie's method to follow her muses, always, in order to achieve an extended portrait of Jackie's process. Taking my cue from her portrayals, I heavily include Jackie's voice and vision that direct my personal and scholarly impressions of the film JULIA, of REAL COOL TIME, and the Royal Project. Our first two meetings were both at her house, in her kitchen, at a small table with a daily newspaper always open. My new watch and blingy purse felt out of place, I felt less than at ease. She offered coffee, and I was grateful to have strong, hot, milky hospitality. The result of our first talks was nervous agreement. She asked me not to tell her too much about my ideas and research. (To keep the process clean.) Neither one of us had ever done this before.

\section{Scene I. Love and Interest, or Montage within a Single Frame}

The first time I arrived at Jackie's home to discuss my interview collaboration with her, I felt the anticipation of meeting a friend, though we were not. I first saw her at Berlin's Moviemento cinema during the 8th Berlin Porn Film Festival 
in 2013, presenting her film JULIA about an economic migrant from former Soviet Lithuania who over 10 years stars as her falling apart protagonist; she did the Q \& A with Julia herself present. In the context of this porn film festival, the hard-hitting documentary about a poetic street sex worker offered a respite from the other films dominated by superficial porno personas. I never saw anything as brutally honest in terms of how the film portrays Julia's sex work and drug use threaded through with her gallows humor, life philosophy, and ambition. In person Jackie was generous, open, apologetic. Julia seemed tired, wan, but sharp. When I began interviewing Jackie some 16 months later, the film had travelled far and wide to festivals, shown on European television, won awards, and yet Jackie was having trouble getting her next project financed. In her stories about trans sex workers funders could not find the usual rescued victims. Jackie is drawn to uncompromising people. I am drawn into her unflinching portrayal of people who are falling apart, but who take responsibility for it.

The documentary style of JULIA is akin to cinéma-vérité and direct cinema in that it largely dispenses with studio settings, except for one interview with a backdrop-the rest is in the wild wherever Julia goes. The editing and specially created waltz score would qualify it as belonging to Bill Nichols' poetic documentary mode, which emphasizes visual associations, tone or rhythmic qualities (2010: 31). And the personal aspect of the filmmaker's involvement with a subject, which effectively heightens the audience's responsiveness, also engenders a performative mode (Nichols 2010: 32). In addition, Jackie's documentary techniques innovate a narrative approach towards their episodic friendship. The storyline is based on fleeting moments in Julia's life caught by Jackie's camera that run against the usual before-and-after division of a gender transition or a recused victim narrateme. This approach to follow the protagonist over a long duration and in media res effectively breaks with the dominant transsexual body narrative organized by the narrative unit of surgical transformation that carries the currency of medical authority. This highly convenient, neat unit of meaning, schematizes the transsexual story into a transition time divided into a before and after, a type of body narrative that Jay Prosser identifies as key to the adaption of a second skin, a layering of one's true self over a less authentic version (1998: 104-105).

The temporality of surgical "transition time" in documentaries bestows cohesion to some trans protagonists, as Prosser points out. However, Kadji Amin warns that the retrospective construction of a transsexual plot (I was this, but now I am that) may be healing for some subjectivities but it comes at "the expense of episodes, even fleeting moments, that would fracture or exceed it" (2014: 220). Jackie's filmmaking practice shares Amin's attention to the fleeting moments of Julia's life as a trans woman; in fact it ignores any scene related to 
a medical gender transition. Given this normative framing of time according to the plot of surgical transformation narratemes, a flattening of experiences into expected patterns of "chronormativity" (Freeman 2007), Jackie's extension of the trans portrait into the breach of fleeting and fracturing moments forms an audiovisual but also inherently temporal activism towards expanding how trans persons can be engaged with as persons, challenging the spectacle of surgical transformation. Instead, by episodically following the protagonist we might attend to the ways other kinds of affective operations palpitate and needle bodies, forming attachments and intense charges.

The significance of what I describe as her technique of making extended portraits can also be understood in terms of portraiture theory. In the context of visual art, Ernst van Alphen explains how artistic portraiture extends beyond a photographic referral to somebody: the portrayer's creative originality serves to consolidate and authorize the self of the portrayed (2011: 47-48). From the point of view of the affective exchange, the portraitist's sustained attention rewards the sitter's sense of a stabilized self. Set against the neatness of the traditionalist portrait and the coherence of trans body narratives, JULIA experiments with combining two kinds of trans cinematic aesthetics: photographic stills that within the film largely appear "unstilled" by montage and are set within a story structured by fleeting, fractured, unresolved episodes. Film's durational quality, Stephen Heath stresses, means that cinematic montage presents the body and voice as "moments, intensities outside a simple constant unity of the body as a whole, the property of a some one," which can be amplified by more radical film aesthetics (1981: 178). The fragmented quality of trans cinematic bodies/voices given in Jackie's documentation of fleeting moments are thus a co-assembly, a labor of love that takes the time to break with temporal conventions.

The film JULIA first introduces us to the muse the way that Jackie met her at the Royal bar, through the photography camera. It was love at first sight between my camera and her, Jackie says. It was clear that the camera wanted her, and she wanted the camera.

With the first two shots we see someone upright, posed and then hunched, set apart by a dissolve to black (fig. 13.1-13.2). Then comes an intertitle that explains the setting of the porn theatre, and the exposition of how to interpret the next image, Julia slumped over (fig. 13.3-13.4). The tumbling of her posture in the cascade of images narrates a downward, sloping trend. But then the documentary film begins by finding a now entirely supine Julia being woken by a colleague (fig. 13.5). In the oscillation from photograph to moving image we find the film's central ruse: the hard working and hard living Julia will rise up again. 

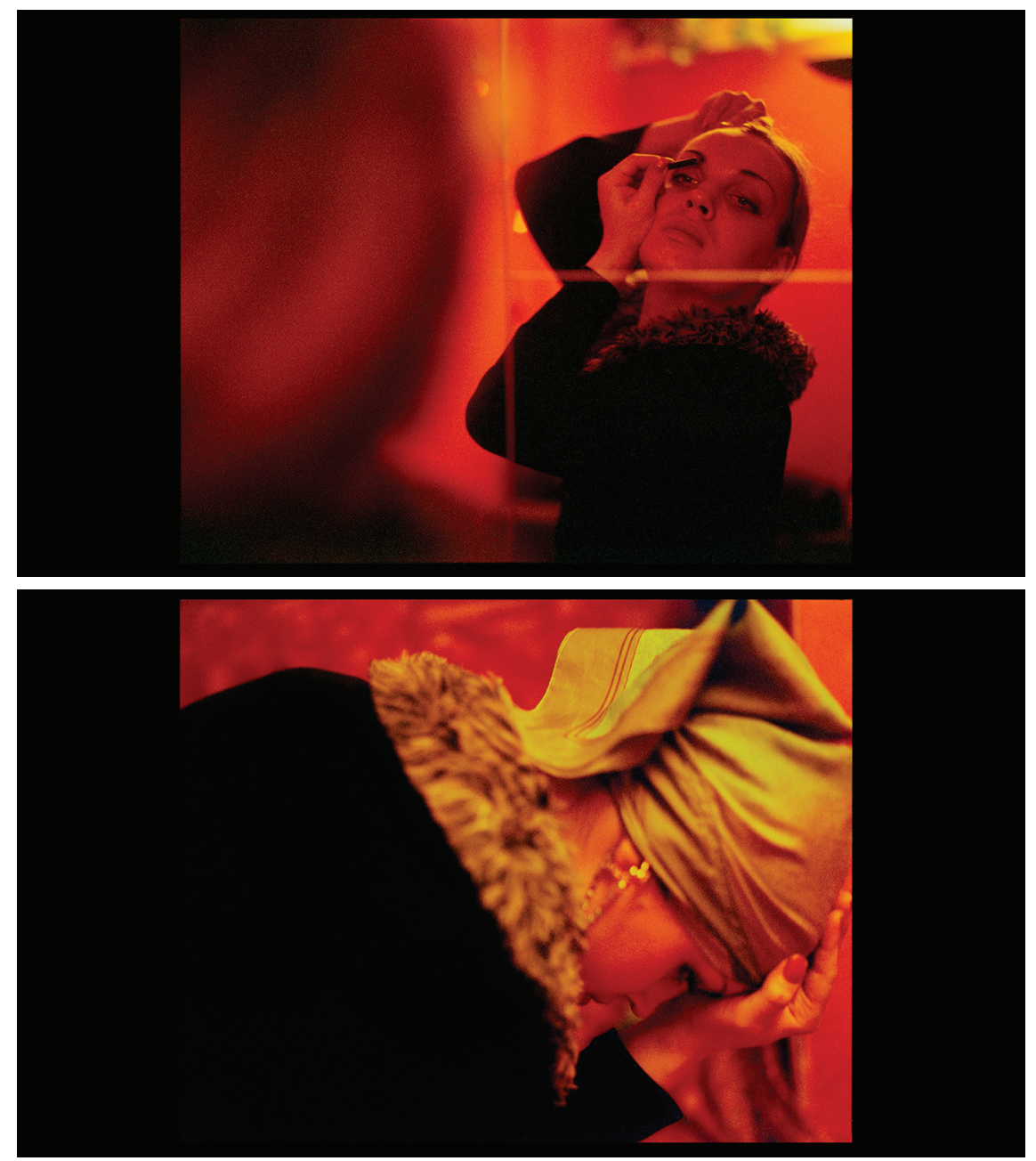

Seit 6 Monaten übernachtete Julia in einem Pornokino.

Julia has been staying in a porno theater for the past 6 months.

For use by the Author only | (c 2019 Koninklijke Brill NV 

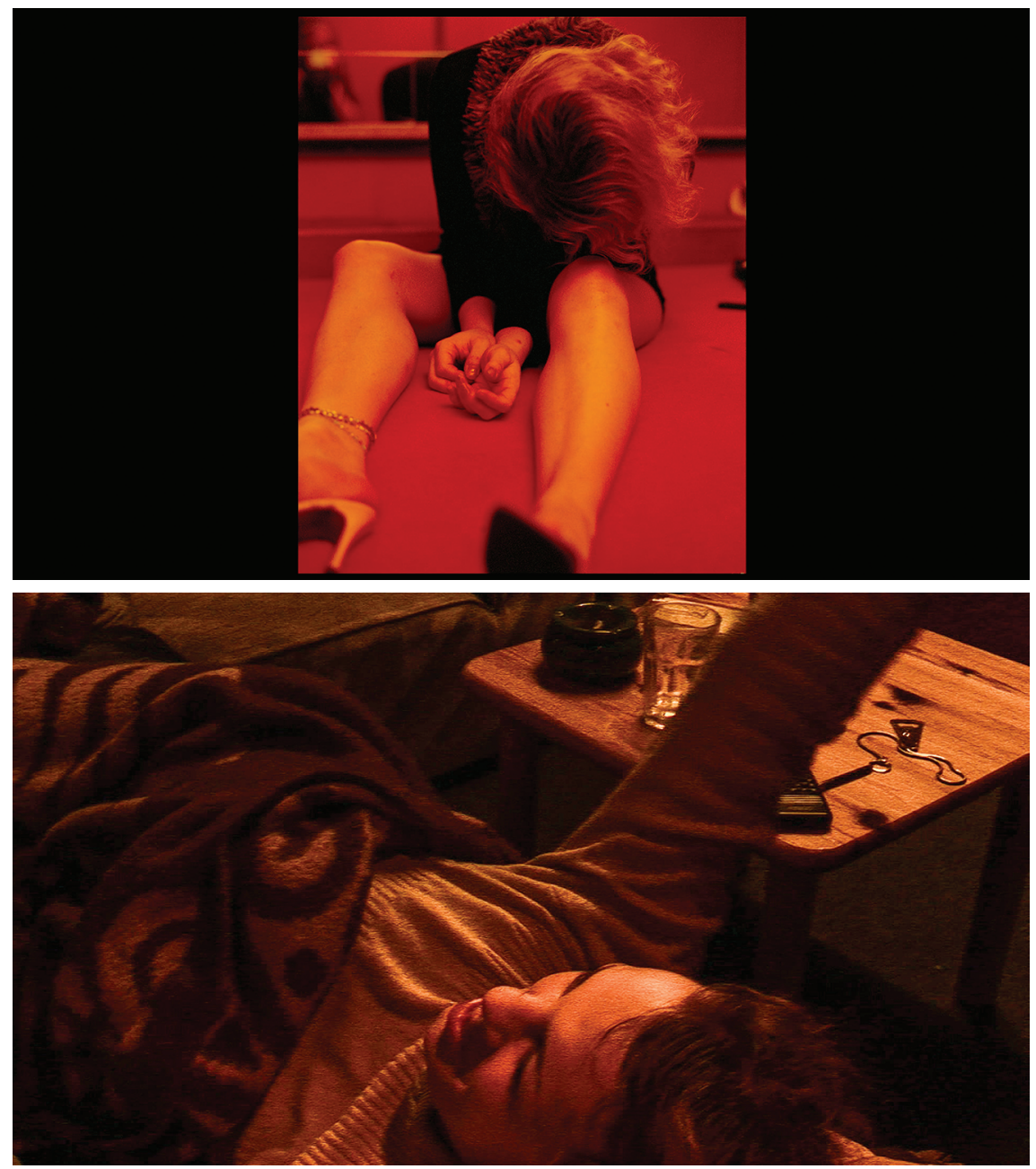

FIGURES 13.1-13.5 Julia in pornokino in JULIA (2013).

(C) J.JACKIE BAIER. KINDLY PROVIDED BY ARTIST.

The raw digital footage of the filmic portrayal is not glamourized in the way that the saturated red prints are. Jackie explains, with a photograph you fall in love with a muse, with a film you become interested in her. The moving image does not just cover a different temporality, but attunes to a different affective structure. Love stiffens, deepens, softens the gaze until it dissolves. Interest, seemingly the most basic affect there is, as Eve Sedgwick and Adam Frank note, is a requirement to move into other affects like disgust or enjoyment (1995: 5). Interest rouses the subject, activates the psychic structure that might become,

For use by the Author only | (c 2019 Koninklijke Brill NV 


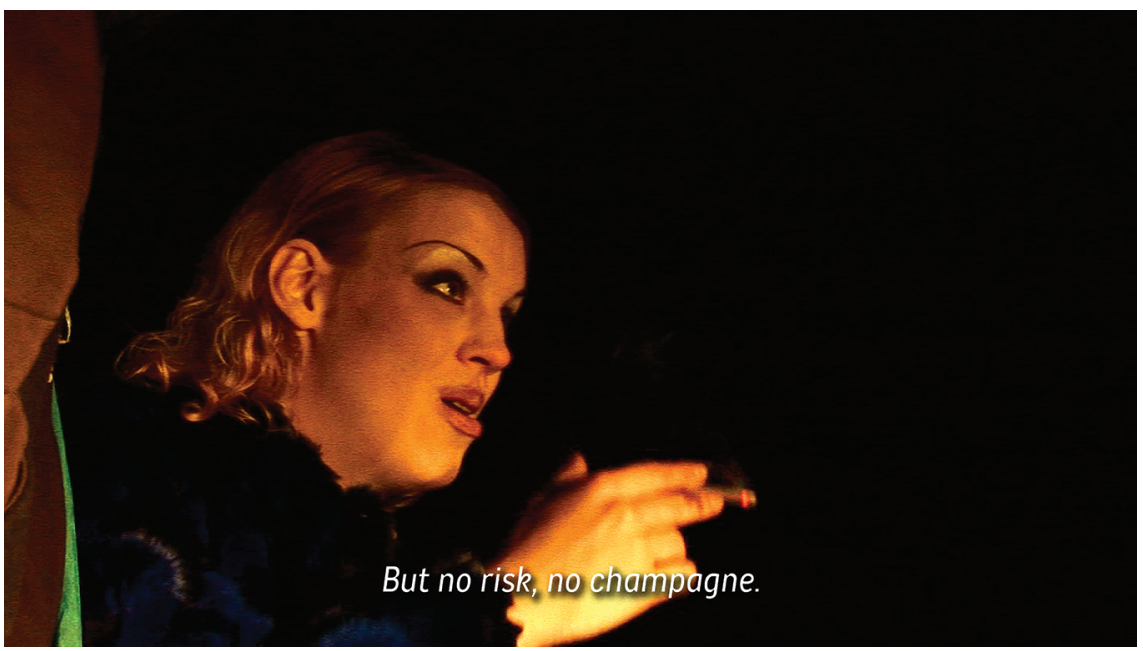

FIGURE 13.6 Julia being interviewed in JULIA (2013).

(C) J.JACKIE BAIER. KINDLY PROVIDED BY ARTIST.

for example, shame (because the interest is caught out as inappropriate). First we must be interested, and then we deflate, deflect, or amplify into other circuits. And this film, of Julia but also of Jackie's interest in her, is about getting interested, about staying interested even when it tips into disgust, or spills out into enjoyment. Julia is followed by Jackie's documentary camera into the toilet at the porn theatre when she vomits, into the public toilet when she jabs into veins in her hands to shoot up, and looks into the car window while she sucks off a very elderly man to catch the sight of her swollen lips with his cum on them. I gagged, I wanted to look away, but the camera stayed, Jackie stayed. This camera asks that we also find this of interest, not to be shocking, but to see this is also part of Julia's uncompromising reality. Despite being sold to a pimp at 18 , beaten up on the streets, extreme alcohol and drug abuse, she refuses to see herself as a victim of her circumstances. She is not compromised; she is uncompromising.

\section{Scene II. Pursuing Dissolution: No Risk, No Champagne}

A fifth of the way through the film Julia disappears from Jackie, then reappears to have a candid discussion about working on the street in which she explains her philosophy, "no risk, no champagne" (fig. 13.6). The montaged sequence that follows combine photographs of Julia with slow motion pans of nighttime urban Berlin to evoke Julia's life on the street she has chosen with open, 

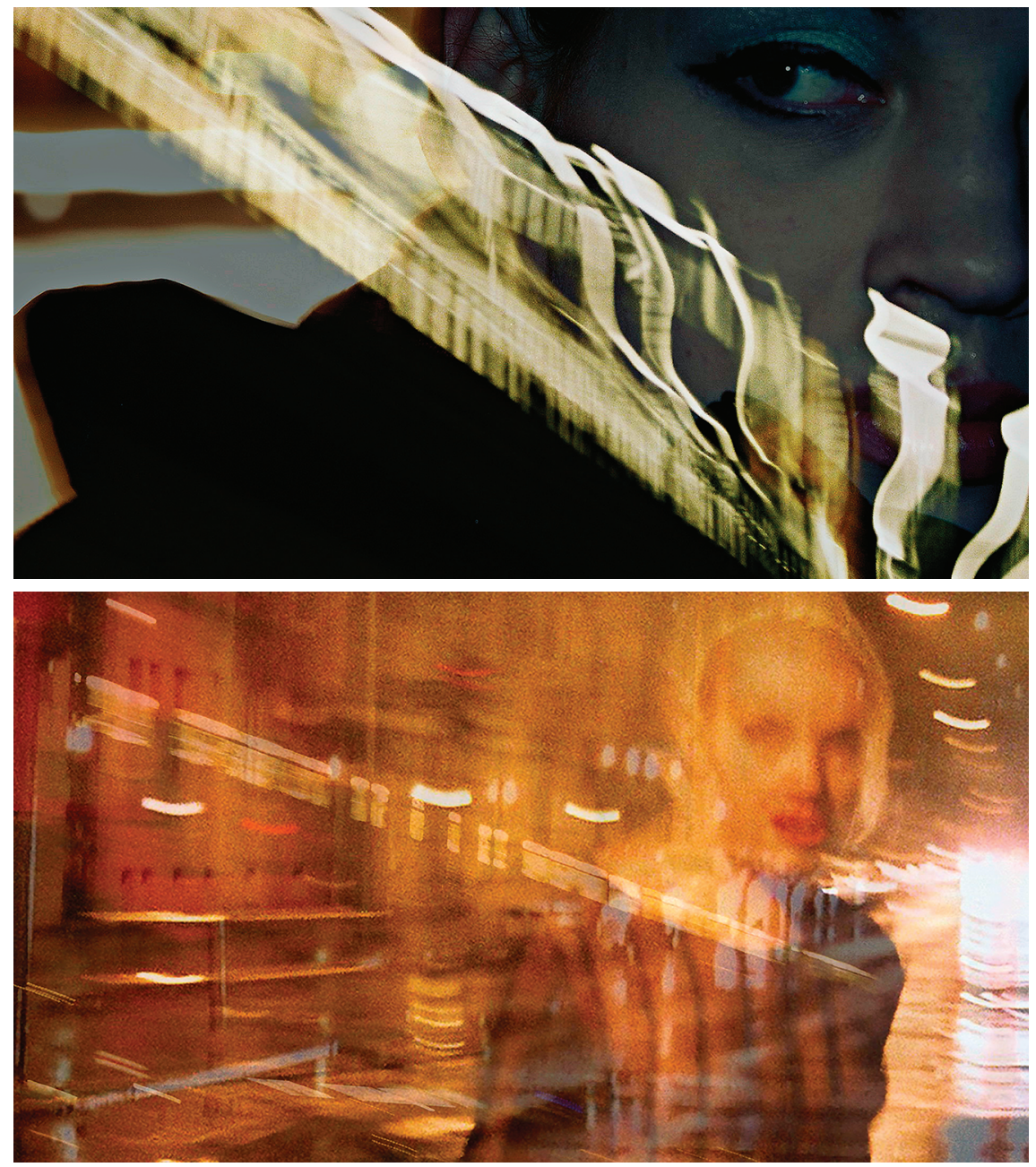

FIGURES 13.7-13.8 Montaged portraits with train in JULIA (2013).

(C) J.JACKIE BAIER. KINDLY PROVIDED BY ARTIST.

though blurry, eyes. Julia's body becomes presenced in the movement of the train, always coming and going, a montage that rhythmically brings the same movement into the edited pans across the still photographs, synched to the 1-2-3 melancholic waltz tempo of the soundtrack. However, the glimpses of Julia's fragmented and blurred face and body are timed irregularly, shifting from zooming in, out, slower, faster (fig. 13.7-13.8).

Like Julia's face caught turning from photo to film, rather than being fixed, the final dissolve of the sequence indicates a getting loose and falling apart

For use by the Author only | (c 2019 Koninklijke Brill NV 
that is something like love. Love pursues dissolution, proclaims Lauren Berlant: "If love is force, though, it is a mess-making force, as its aim is to dissolve toxic sureties" (685). The montage sequence of still images breaks with being a registration of reality; its radicality is to inquire into the image itself, its ontological properties and affective structures. When I suggest that Julia is one of Jackie's muses, this is what I'm referring to, not to the object that fascinates but to the face that teaches Jackie something about what an image is or can do. This kind of portrait achieves what she calls "a montage within a single frame," that is when it contains the kernel of story-life happening - that fractures the frame into a diptych or triptych or, I would add, a mini-film .GIF of a few frames. These are images of the making of someone in parts or pulses, not the finding of them whole, a perfect specimen, which is surely a toxic surety. In the pans, the eye is directed to see past stigmata that fix a spoiled identity on someone, to chance a graze or encounter, to shift from a passing interest into love at the point of dissolve.

Jackie wants to hear and see something new, to shake loose from the composition habit of setting a body into the vanishing point (she tells me, "if I use it, everything dies"). To capture the moment when montage occurs within one frame, Jackie must allow life to enter the frame-the opposite of composing. Jackie does not seek safety in a tradition or school; she remains vulnerable to things just happening. Accordingly, these portraits offer a point of view without the heart of gold or suffering victim cloaking usually overlaid onto prostitutes. "I'm not trying to make 'my' statement, somehow I'm trying to get loose." Like a kind of flaneur. She mistrusts the Idea as such; these gestures to capture a montage are to loosen the idea of who Julia is at any given moment in time. "No human story is cliché, if only you listen, wait for its truth," she patiently explains. In the movement away from the monumental ideal or clichés, it is scary, it gets violent. And lonely without a common ground of the accepted point of view. Unlike the shadowed creatures of Peter Hujar's Night photographs, the opacity of her nighttime portraiture produces a vision of shimmering stars that populate Jackie's universe. Glimmering faces, catching the glare of streetlights and carlights: a portrayal full of mutual complicity (fig. 13.9).

There was always a new event in Julia's life, a reason to continue. "I thought I have to stay with it, I have to stay with her." These episodic flashes are encounters with a shifting truth of love and its mess-making force, like Walter Benjamin's constellations flashing an illumination across the sky (Wieseltier 2007: $\mathrm{x}$ ). The narrator function of JULIA is thus made over into an affective vacuum of attending, waiting and bidding rather than a subject who judges; or, to put it another way, the narrator is no master, but lead by the unsovereign love of the characters. "I work with the impulse and the desire of the material — the protagonist is not 


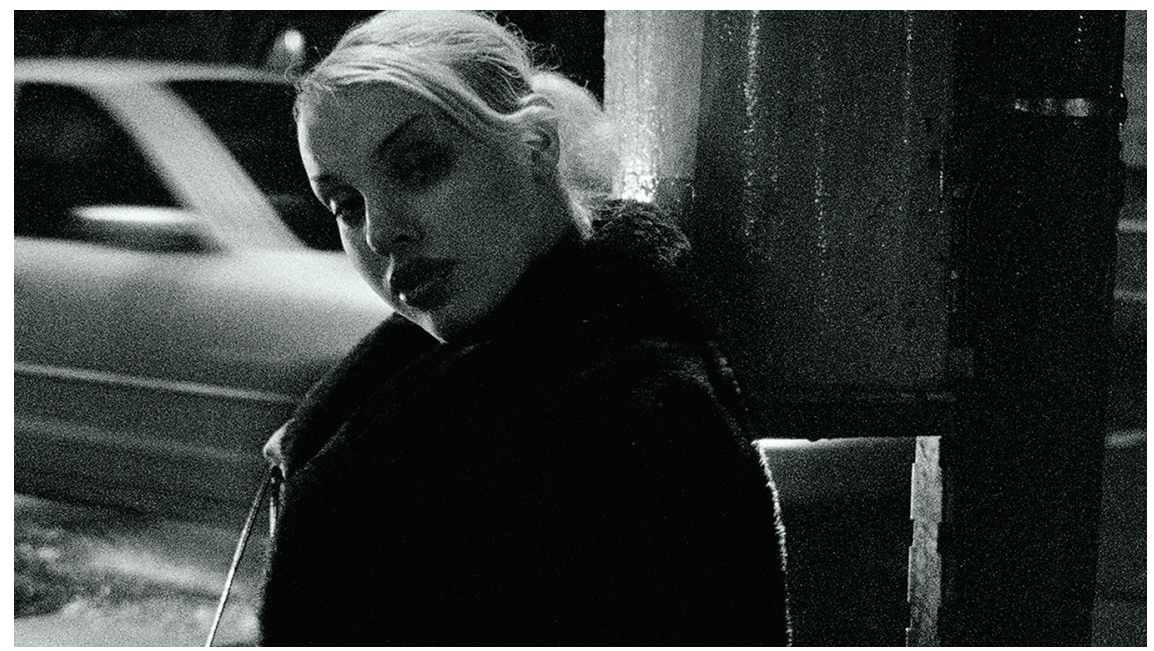

FIGURE 13.9 Julia portrait in street in JULIA (2013).

(C) J.JACKIE BAIER. KINDLY PROVIDED BY ARTIST.

just a subject but a medium. She is not an archetype or a regular charactershe exists! There is no language for her already, I must find out how to tell this story." Jackie found shots that would create an atmosphere of interest and from her days directing soap operas she learned how the composition of the shot's mise-en-scene is crucial to supporting the narrative arc of the actor's emotions. Principally, she uses the medium-long "American shot," a film composition that she explains is helpful for always including the context of her human subjects. For Jackie, a photographic framing that lacks foreground does not make sense, not when you want to ground the protagonist in scenes of uncompromising selfhood - set against something. But to keep the ever on the move Julia in this vision, Jackie has to dance, to walk backwards as she charges forward, or swing around as she marches on. The fractured series of encounters that compose Julia's story are one part of developing an adequate cinematic language for Julia's wholehearted embrace of brokenness: "she was someone who touched my heart, a story that broke my heart." The resulting aesthetic and affective narrateme organizes around the time of dissolution, a time of uncompromised love.

\section{Scene III. A Painful Impression: Becoming the Zero Point of Perspective}

"After so many years in soaps, the real world was reborn for me, I wanted to go see something and deal with it directly." Documentary was like returning 
to drawing-you see something for the first time. "It teaches me to break with habits, that each time I deal with something directly I try to get away from what I know, any foundations, and have to find out again. What is the story here?" Jackie had been a drama series director and scriptwriter for German soaps for more than 15 years, prior to and after her transition. She grew up wanting to be like Ingrid Bergman, heard about Renée Richards when her bio-pic came out with Vanessa Redgrave playing the transsexual tennis star, watched Fassbinder's films and sympathized with the protagonist of In a Year with 13 Moons, and came to know Warhol's depictions of Candy Darling, especially loving Women in Revolt, and falling for the series "Ladies and Gentleman" (1975) with bright, lurid characters. She also lived through the AIDS crisis, and was a contemporary of the Dutch transsexual cabaret star and nightclub queen of Germany, Romy Haag, whom she has portrayed for poster art. She was attracted to the intimacy of Richard Avedon's images of feminine people and the rock ' $n$ ' roll roughness of Anton Corbijn's stylized masculinity.

During 1997, when she reintroduced herself to her work environment and started to lose jobs, something fundamental shifted: "somehow everybody I knew then felt quite uncomfortable with the fact that they should address me as a woman. Even some of the other transsexuals I've met were constantly afraid that we produced a somehow painful impression." The problems she faced with occupying her new social position as a woman led to a creative crisis as well. "The point zero of perspective was empty. The mirror, center of reflection, was broken" (Baier 2012: n.pag.). She explains that transitioning meant loosing her perspective from a particular social role, and during 199799 her eyes would not focus. She picked up a camera to try to connect to a point of view, borrowing the technological position of the camera's eye for her own, using the prosthesis to see but also as a social connector that enables her to enter into a social scene and "get into contact" with people. Though the medical doctors said nothing was wrong with her eyes, and in time it did resolve itself, Jackie feels she retrained her perspective by using a photographic camera's autofocus. But she felt as if these resulted in bad, though focused photographs. She came to prefer the experiments of her own blurred vision, when the camera registered an impression of emergence, which was much more interesting for her to look at than a readymade image. She likens the experience to what Walter Benjamin calls the loss of the narrator function, Der Eräzhler (also known as the storyteller), which left no subjective position to speak from in novels written after the Great War (1980).

She soon found a weekly queer party called House of Shame, hosted by the first transsexual woman she had met who was not afraid to be one, the legendary Chantal. Week after week she would go in with her old Nikon. She did 
not want a picture-who could shoot in those conditions? - she wanted to get connected. She writes,

I walk past a room, look around me-it is dark and it is crowded. Music at full volume. A beer at the bar, further down a group of men at the soccer table, behind it - kind of a backstage room, but it's not worth the name, it's just a room behind a door with a curtain, unlocked since all the keys got lost somehow. [...] There is no place to hide, no secret room, where you can arrange meetings for a portrait before or after the show. No more caves, no more silent moments. Everything happens in the middle of the public, every action is party action, everybody is rolling around, dancing, spilling beer and vodka. Men are shouting to make themselves heard, people pushing forward, men who head for the urinal or for the toilets and the coke. Everything, every movement, even holding a camera in my hand and lifting it to the eye-it's all in the middle of performance. [...] Everything seems to be amorphous, the lighting disintegrates the forms. I throw myself into the revolving darkness and as I point and shoot, I desperately wait to be struck. [...] I'm looking for a story that hides in the dark. (Baier 2012: n.pag.)

"Affect is not in the object; nor is it in the figure," writes Clough, it is "an event of dead time seething with vibrations, with rhythms ready for propagation or infection" (2010: 228). Some of these photographs depicting stories that hide in the dark from the House of Shame days are now self-published in a magazine series Jackie calls REAL COOL TIME. ${ }^{3}$ Taken without a flash, each shot implicates Jackie's experience of the party as an event of dipping into affect's reservoir of dark, dead time. Shooting in the dark, literally, each photograph activates a possible connection, or disconnection, or gropings. The camera being lifted and clicked potentially ramps up the vibrations of affective intensity, joining in with the musical rhythms, the choreography of coke snorting and beer spilling, percussing along with the rhythms of a queer party spreading out in affective spirals of movement, spillage and jostles for attention. In the taking of these photographs affect is not in the object being referred to, nor is it in Jackie herself. The performance of taking party photographs triangulates the camera with human subjects on substances and high on feeling. The resulting high grain prints are the only way to make something legible of the low-light

3 REAL COOL TIME is available to purchase on Baier's website under personal projects and in selected Berlin bookstores. 
photographs, while propagating the affect of being real cool, and also a sense of being real. Without high definition, distance to define the scene, or ability to properly frame people, the photographs place Jackie smack-dab into the vibratory space of the party's wildly transmitted and circulated affects, and the viewer into the off-kilter and charged place of the ensuing ruckus.

\section{Scene IV. Methods for De-individualizing and De-skilling: an Unmoored, Opaque Vision}

Jackie found a kinship to her trans aesthetic of shooting without a foundational, subjective perspective in the are, bure, boke style of photography, translated as "grainy, blurry, and out-of-focus," popularized in Japan in the late 196os, that challenged staid versions of European style photojournalism. Whether through deliberate "de-skilling" of camera technique, or simply her visual experience, Jackie found her way back into social contact through sticking to the truth of her unmoored, opaque vision, and developing a new sociality through its affective force. Whether drunk, love high, exalted, addressing, quizzical, attention seeking, showing off, feeling sexy, or feeling down, Jackie says, "Follow the protagonist. Always." That is her method. To work away from the zero point perspective; "I could not see, the faces could not come into focus." It is not just the face; it is the place. "I felt I had to give them context." This is not portraiture that rehabilitates the outsider, conferring dignity. Her particular practice explores the possibilities for capturing their rushed, drugged individuation on the brink of their perhaps forever dissolve.

She is currently finishing her Royal Project, begun during her working days in the Royal Club, in which most all the working girls were trans women. Now some ten years on from when she was working regularly there, Jackie is tracking down her old colleagues to reshoot their portraits and talk with them about where their life is now. The trained flamenco diva from South Africa, La Bianca is still performing and is portrayed backstage at a club. Barely gazing at herself in the mirror, Bianca embraces her lithe body (fig. 13.10). The fuzziness of a body to the right of the camera bars our entrance to seeing all of Bianca's reflected body in the mirror.

Jackie's decisive moment here is not the decisive moment of Bianca's life in the Henri Cartier-Bresson tradition of claiming to capture the overall significance of an event through its expression in forms. She does not pretend to unravel Bianca's transformation for us; a slice of her subjectivity is available, but only that which she wants to show-the rest remains in her mind's eye and behind a protective fleshy shoulder. Jackie does not lead us out into the world of 


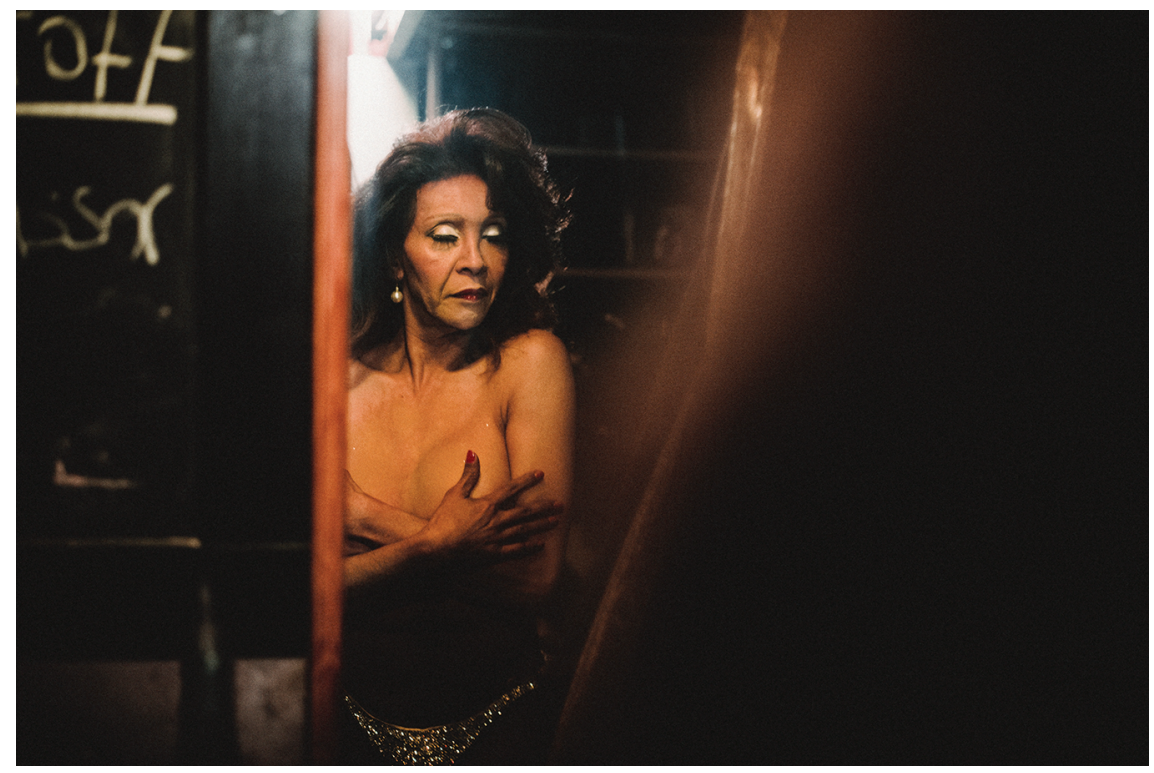

FIGURE 13.10 La Bianca Portrait in Royal Project (2013).

(C) J.JACKIE BAIER. KINDLY PROVIDED BY ARTIST.

decisive moments for trans woman; with her we enter into semi-public spaces of erotic fumbles and jumbles of people that clang together with the potential of dead time, those vibrations and affective rhythms ready for propagation or infection. Her portraits within the porn theatre and the club are spaces of transaction and interaction, of dissolving social roles. More than a bedroom in which sex becomes private, the people we meet through Jackie are in a kind of shared boudoir. Historically, the boudoir is an antechamber just off the side for some people to congregate within, but not all. It is not exactly the bedroom, though it can be comfortable in there to lounge. It frames the social activity that occurs between the bedroom and the dining room: the adjacent room between public and private spaces. It draws its name from the French bouder (to sulk), and was a place to withdraw to, for the privacy of female talks, or meeting with one's romantic partner.

It is also a space of preparation to be seen by others, decorated in mirrors, and famously in the Marquis de Sade's story of the boudoir fully covered in mirrors (1795) that allows for sexual acts to be infinitely doubled and seen by all. Not very discreetly the many performers that Jackie shoots backstage and in sex clubs have meaningful mirrors around them. Mirrors and trans people form a horrible cliché most of the time, as they suggest trans people are not what they seem, or that they are all visual spectacle on the surface, lacking a 
real depth. But in the history of photography, mirrors are also particularly associated to trans women. The Lou Reed song, "I'll be your mirror," sung by Nico from the Velvet Underground, was adopted by Nan Goldin to become the title of her midcareer retrospective (1996), portraying her New York family of fairies and her own abusive relationship (first shown in the explosive 1986 show Ballad of Sexual Dependency). After Goldin's exhibition and catalog came out, a whole generation of documentary photographers seemed to have found their credo, muses Jackie (2012: n.pag). She was angered that "instead of carefully examining their own motivation many documentary photographers and filmmakers simply claimed to be the 'mirror' of their protagonists" (2012: n.pag.). For her, experiencing a lack of stable subjectivity meant she would disappear into the center of the mirror as the subject of observation, so the only apparently neutral approach of pure reflection did not work. She always saw herself as the crack in the mirror.

Mirrors do appear in Jackie's work, but not to see the protagonist clearly in or through them. The mirrors in dirty public toilets are heavily scratched in JULIA, the dressing room mirror catches the photographer watching Bianca emerge; they are not to be trusted or taken as the true account of that person, or the event. The poem Jackie references to describe her own experience of the mirror as "crack'd" is by Alfred Lord Tennyson, "The Lady of Shalott" (1833), with the key verse being:
Out flew the web and floated wide;
The mirror crack'd from side to side;
"The curse is come upon me," cried
The Lady of Shalott.

Tennyson's mirror is the cage of the Lady of Shalott, the space she is restricted to living within, and once she turned from it, it loudly "crack'd." She escapes, but then is forced to live at a distance from society. Like Jackie turning away from her male assignation towards a life as a woman, she found it impossible to hold a mirror to society, or even to herself. She explains, "because the subject of that action simply didn't exist anymore" (2012: n.pag). She had turned away, and saw differently now, though forever banished from regaining a secure social position. Goldin is known for not turning away from the harsh realities of her subjects. But whether shot cleanly or with the effect of a blur, Goldin's claim for mirroring is that it allows her to give back beauty to those who are twisted, or feel unkindly. Her unexamined cisgender privilege to mirror gendered realness back onto these subjects makes these images not just suspect, but frustratingly distorting of trans beauty. 
Goldin's second book portraying trans women, The Other Side (1993), was shot in Manila, Bangkok, Boston, Berlin and New York; it claims to be a new type of exposé on trans and drag life on the "other side" of the mirror. In the introduction Goldin writes, "The pictures in this book are not of people suffering gender dysphoria but rather expressing gender euphoria [...] The people in these pictures are truly revolutionary; they are the real winners in the battle of the sexes because they have stepped out of the ring" (1993: 1). Jackie responds obliquely by saying of her own encounters:

It is difficult for me to see the people I met here-I include myself-as the "real winners of the battle of the sexes." "Revolutionaries," well, maybe; "Fighters," for sure- but we could never allow ourselves a moment of peace. But somehow, we got stuck. Between cultures, between sexes. And without any idea how things would go on from here. Or if they would go anywhere at all. (2007:37)

Jackie shoots in the meantime, the real cool time of being in this room, this boudoir. Will she go anywhere, I do not know, and Jackie does not know either. She tries again and again to capture the moment the mirror "crack'd," with all its resounding aural threat of destruction - splitting, coming apart, crazed and deranged, splintered and shattered. A release from the tightly woven web of our predictable normative forms of life, but also engendering the question of what now, where do we go from here?

\section{Conclusions: To Hold a Sightline with Your Muse, Trans Women Loving Women}

The cinematic and photographic bodies of Chantal, Julia, Bianca, and also her recurrent muses from the Royal expand and dissolve according to the long nights and short days of their lives. This inverted, transitory tempo of those "risk identities," like sex workers, transgender, or club kids, is out of joint with productive citizenship temporalities (Halberstam 2005: 10). Jackie's affectively attuned perception feels for the broken or disjointed sense of these selves. She tries to make honest visual registrations of how being out of joint, out of focus, forms a contrapuntal rhythm to the chrononormative beat. The aesthetic choices then are uncompromised choices, routed through the impulse and the desire of the material, and the possibilities afforded by the lens that joins them. The force of her affective operations, I have showed, emerges within the triangulation of protagonist, photographer and camera that overlay onto 
emergent subjectivity, a psychic apparatus of feeling, and a social prosthesis. The protagonist-cum-muse is not just a subject, but also a medium. The prosthetic camera frames a social composition in order to allow life and its dissolution to come into a blurry focus. The lens mediates an affective exchange, coming to form a kind of extended portrait not just of the protagonist or of the photographer, but of the episodic time of the relation, of the encounters, as things fall apart, commune again. Counter to contemporary portraiture theory that emphasizes the dialectics between presence and absence (see Woodall 1997), the out-of-focus bodies and nocturnal creatures that Jackie so clearly loves are shown in the loving, dissolving aesthetics of their shared sightline. Jackie's out-of-focus photographic vision embraces the lingering halos of former selves, and finds evidence of emerging, bright beacons. Banished from society, denied authenticity, and resistant to a stabilized self present in the "after" of a corrective surgery, Jackie's protagonists model other kinds of individuation, uncompromising forms seething with risk and sparkling with the bubbles of cheap champagne.

Where is Jackie the portraitist in what Linda Nochlin describes as "the meeting of two subjectivities" in the portrait itself (qtd. in van Alphen: 21)? InJULIA the tracking shots evoke a punter or john in a car making a consideration of her beauty, a bid for her attention and sloppy affections. But on the street, close up, the camera caresses and holds Julia, who disappears into her own thoughts seemingly blissfully unaware of where she might be squatting. Rather than fly on the wall, Jackie's camera intervenes in the getting wild - a kind of prosthetic vodka bottle for Julia, something that loosens her up, that she trusts and wants. She asks Jackie to get the camera out, to create a dance with her, a tango through the night. We know Jackie tries hard to keep Julia in her sightline. But Jackie is rarely seen, emerging most touchingly at the end of the film when we see her shoulder and jean jacketed back leaning in for a hug after Julia says, "I'm a creature of God. But a weird (distorted) creature. God was not paying attention when I was born" (fig. 13.11).

In Jackie's studio portraits, the glamour of the backlit headshots and smoldering pouts is a nod to her first loves she met through the eye of Andy Warhol: Jackie Curtis and Candy Darling. They are also uncompromising trans feminine persons, brilliant and tragic, who knew how to get loose. Portrayed as heartbreaking starlets, they were all glitter and trash, mouthy and tender. Looking again at the surviving Royal friends in a studio shoot, Jackie strips her love down to "only two people with a lot of history looking into each other's eyes." These images remove every distraction, it is only about the person, that face and mood. The lens implores, what have your eyes seen, what has happened? Even without the cluttered foreground of a club, home or 


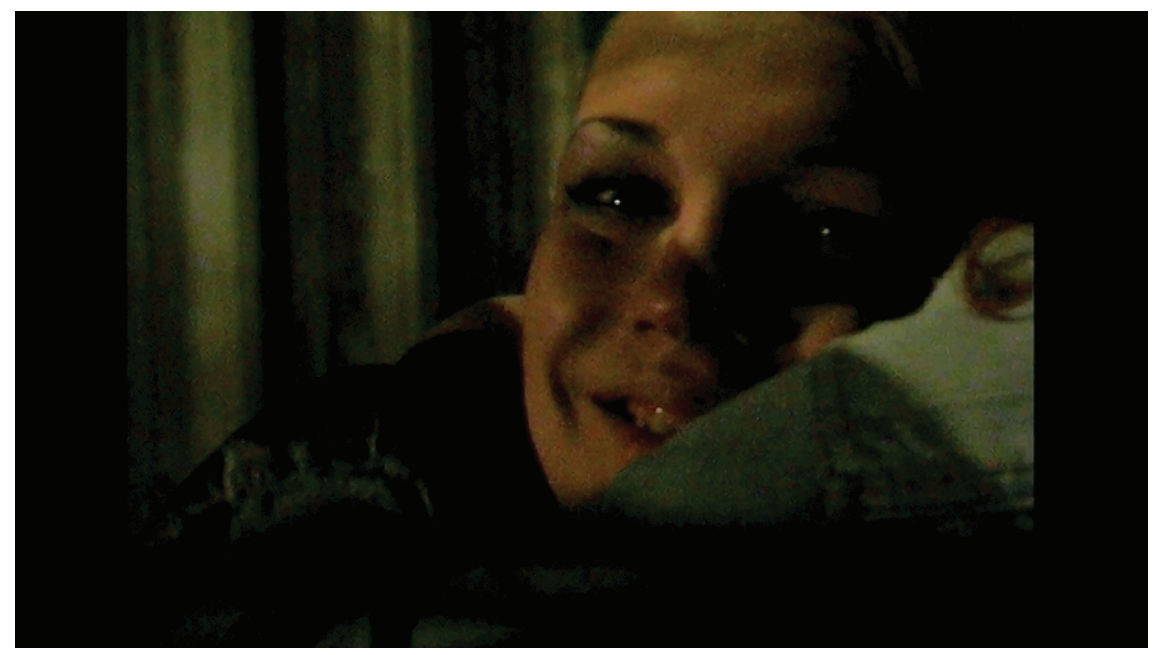

FIGURE 13.11 Jackie hugging Julia in JULIA (2013).

(C) J.JACKIE BAIER. KINDLY PROVIDED BY ARTIST.

toilet in the image, the context of their prior relationship at Club Royal that frames the exhibition inevitably colors the portraits. Pronounced in Jackie's artistic practice is the charge of the affective exchange within the durational process of creating portraiture. Put on view is the complicity between the person being portrayed and the portrayer. The aesthetic operations of being out-of-focus, decentered, and episodic challenge a reading of two subjectivities united in a meeting. This kind of more traditional portrait framing in terms of "who are you, and who am I?" would open the image to interrogating their gender identities, which Jackie flagrantly avoids. The mutuality of their affective exchange in the portrait becomes generative of enflamed bodies that flash mildly horny affection, a sightline match bubbling up with the interest (and potentially mess-making love to come) cajoling, "Come on, show us what you've got."

\section{Works Cited}

Amin, Kadji. “Temporality.” TSQ: Transgender Studies Quarterly 1.1/2 (2014): 219-222.

Alphen, Ernst van. "The Portrait's Dispersal: Concepts of Representation and Subjectivity." Interfaces: Portraiture and Communication. Ed. Gerardo Mosquera. Madrid: La Fabrica, 2011. 47-62.

Baier, J. Jackie. “The Mirror Crack'd." Unpublished Artist Statement, 2012. 
Baier, J. Jackie. “Artist Statement.” Sex Work. Kunst, Mythos, Realität Catalog. Ed. Stéphane Bauer, Boris von Brauchitsch, Katharina Kaiser, Maike Leffers, Jörg Leidig, Judith Siegmund, and Ulrike Solbrig. Berlin: Kehrer NGB K, 2007.36-37.

Benjamin, Walter. Gesammelte Schriften. Vol. II. Ed. Rolf Tiedemann and Hermann Schweppenhäuswer. Frankfurt am Main: Suhrkamp, 1980.

Berlant, Lauren. "A Properly Political Concept of Love: Three Approaches in Ten Pages." Cultural Anthropology 26.4 (2011): 683-691.

Brinkema, Eugenie. The Forms of the Affects. Durham: Duke University Press, 2014.

Clough, Patricia. "Afterword: The Future of Affect Studies." Body \& Society 16.1 (2010): 222-230.

Freeman, Elizabeth. Time Binds: Queer Temporalities, Queer Histories. Durham: Duke University Press, 2007.

Getsy, David J., Trish Salah, Julian B. Carter. "Introduction: Trans Cultural Production." TSQ: Transgender Studies Quarterly 1.4 (2014): 469-481.

Goldin, Nan. The Other Side. New York: Powerhouse Cultural Entertainment Inc, 1993.

Halberstam, Jack (Judith). In a Queer Time and Place: Transgender Bodies, Subcultural Lives. New York: New York University Press, 2005.

Heath, Stephen. "Body, Voice" [1979]. Questions of Cinema. Bloomington: University of Indiana Press, 1981. 176-193.

Ingold, Tim. "That's enough about Ethnography." HAU: Ethnographic Theory 4.1 (2014): 383-395.

Lawrence-Lightfoot, Sara, and Jessica Hoffman Davis. The Art and Science of Portraiture. San Francisco: Jossey-Bass Wiley Imprint, 1997.

Nichols, Bill. Introduction to Documentary. 2nd ed. Bloomington: Indiana University Press, 2010.

Ngai, Sianne. Ugly Feelings. Cambridge, MA: Harvard University Press, 2005.

Ngai, Sianne. Our Aesthetic Categories: Zany, Cute, Interesting. Cambridge, MA: Harvard University Press, 2012.

Prosser, Jay. Second Skins: The Body Narratives of Transsexuality. New York: Columbia University Press, 1998.

Sade, Marquis de. Philosophy in the Bedroom [1795]. Trans. Richard Seaver and Austryn Wainhouse. New York: Grove Press, 1971.

Sedgwick, Eve Kosofsky, and Adam Frank, eds. "Shame in the Cybernetic Fold: Reading Silvan Tomkins." Shame and Its Sisters: A Silvan Tomkins Reader. Durham: Duke University Press, 1995. 1-28.

Steinbock, Eliza. Interview with J. Jackie Baier. Field Notes, 20-23 March; 3-6 July, 2015. Steinbock, Eliza. Interview with J. Jackie Baier. Field Notes, 8-10 December, 2016.

Sullivan, Nikki. "The Somatechnics of Perception and the Matter of the Non/Human: A Critical Response to the New Materialism." European Journal of Women's Studies 19.3 (2012): 299-313.

\section{For use by the Author only | ( 2019 Koninklijke Brill NV}


Tennyson, Alfred Lord. "The Lady of Shalott" (1833). The Camelot Project. Web. 30 April 2017.

Wieseltier, Leon. "Preface." Walter Benjamin Illuminations: Essays and Reflections. Ed. Hannah Arendt. New York: Random House, 2007.

Woodall, Joanna, ed. Portraiture: Facing the Subject. Manchester: Manchester University Press, 1997 .

\section{Filmography}

Bianca, Or Love Is All You Need. Directed by J.Jackie Baier. Spain/Germany: ALHENA, Amard Bird Films, Jürgen Brüning (in production).

House of Shame: Chantal All Night Long. Directed by J.Jackie Baier, Germany: Jackie Baier Filmproduktion, 2010.

JULIA. Directed by J.Jackie Baier, Germany: Gemma Bak Filmproduktion, Jackie Baier Filmproduktion, Just a Moment, 2013.

\section{For use by the Author only | ( 2019 Koninklijke Brill NV}

